\title{
Prototype Sistem Pemantau Batas Beban Pada Kapal Penumpang
}

\author{
Iswahyudi, Sumardi \\ Universitas Jember \\ Jl. Kalimantan No.37 Jember 68121 Jawa Timur Indonesia \\ e-mail: yudiokyes@gmail.com
}

\begin{abstract}
ABSTRAK
Abstrak - Kapal penumpang merupakan sarana penting dalam bidang perhubungan air di wilayah Indonesia yang merupakan negara kepulauan, dimana pulau satu dengan yg lain dipisahkan oleh laut. Akan tetapi aspek keselamatan sering kali diabaikan dengan memasukkan muatan tanpa menimbang dan memperhatikan batas beban angkut kapal, ini dapat menyebabkan kapal tenggelam saat terjadi cuaca buruk atau gelombang tinggi. Dalam prototype ini Atmega 32 digunakan sebagai otak yang mengontrol dalam proses pengiriman secara elektronik. Untuk mencegah kelebihan muatan pada kapal penumpang maka dilakukan penimbangan menggunakan sensor berat loadcell resistance $2 \mathrm{~kg}$ dengan berat maksimal 2000 gram yang direpresentasikan sebagai berat maksimal kapal, selain itu alat ini juga dilengkapi sensor cahaya dan motor servo sebagai palang pintu dan webcam yang berguna untuk mengambil gambar setiap kendaraan yang masuk ke dalam kapal penumpang. Data yang diperoleh dari hasil timbang akan ditampilkan pada LCD dan hasil foto akan dikirim ke komputer atau laptop dengan mengunakan komunikasi serial RS-232 untuk disimpan sebagai data base. dari hasil pengujian prototype ini diperoleh kesimpulan bahwa dengan berat beban dari 0 sampai 1,600 gram dengan persentase kesalahan sebesar $0,3 \%$ karena output dari load cell hanya maksimal 4 Volt.
\end{abstract}

Kata kunci: ATmega 32, sensor berat Loadcell resistace $2 \mathrm{~kg}$, palang pintu, webcam, LCD, RS - 232

Copyright @ 2019 Universitas Muhammadiyah Jember.

\section{PENDAHULUAN}

Sarana transportasi masal memang sangat diperlukan saat ini, salah satu di antaranya adalah kapal penumpang. Kapal penumpang merupakan sarana penting dalam bidang perhubungan air di wilayah Indonesia yang merupakan negara maritim dengan jumlah pulau terbesar di dunia, yang memiliki kurang lebih 17.504 pulau yang membentang dari Sabang sampai Merauke yang dipisahkan oleh lautan dengan garis pantai $81.000 \mathrm{Km}$ serta luas wilayah laut sekitar 5,9 juta $\mathrm{Km}^{2}$ (UU Nomor 17 Tahun 1985 ). Akan tetapi aspek keselamatan sering kali diabaikan dengan memasukan muatan tanpa menimbang dan memperhatikan batas beban angkut kapal, ini dapat menyebabkan kapal tenggelam saat terjadi cuaca buruk atau gelombang tinggi. Hal tersebut diatas yang melatar belakangi ide penulis untuk membuat prototype sistem pemantau batas beban pada kapal penumpang [1].

Sistem ini berfungsi untuk mencegah terjadinya kelebihan beban muat kapal yang diakibatkan oleh keteledoran penjaga kapal yang memasukkan kendaraan secara sembarangan tanpa memperhatikan beban angkut maksimal kapal, selain itu alat ini juga dilengkapi dengan kamera yang berfungsi untuk memfoto setiap kendaraan penumpang maupun kendaraan barang yang akan memasuk kedalam kapal.

\section{KAJIAN PUSTAKA DAN PENGEMBANGAN HIPOTESIS}

\subsection{Mikrokontroller AVR Atmega 32}

Mikrokontroller adalah salah satu device yang terintegrasi dengan I/O Port, RAM, ROM sehingga dapat difungsikan keberbagai keperluan kontrol. Salah satu jenis mikrokontroller adalah Atmega 
32 yang merupakan low power CMOS 8 bit, dikembangkan oleh Atmel dengan arsitektur RISC ( Reduced Instruction Set Computer) yang memiliki kecepatan yang sangat tinggi dalam eksekusi intruksi. Jenis mikrikontroller AVR dikelompokkan kedalam beberapa jenis yaitu Attiny, AT90xx, Atmega, dan AT86RFxx. Dimana yang membedakan adalah memori yang ada pada perangkat tersebut. Pada gambar 1 bereikut merupakan konfigurasi pin yang ada pada mikrokontroller Atmega 32.

\begin{tabular}{|c|c|c|}
\hline$(\mathrm{XCK} / \mathrm{TO})$ PBO 1 & 0 & 40 PAO (ADCO \\
\hline (T1) PB1 2 & \multirow{19}{*}{ ATMEGA32 } & 39 PA1 (ADC 1) \\
\hline (INT2/AINO) PB2 3 & & 38 PA2 (ADC2) \\
\hline (OCO/AIN1) PB3 4 & & 37 PA3 (ADC3) \\
\hline$\overline{(\overline{S S})}$ PB4 5 & & 36 PA4 (ADC4) \\
\hline (MOSI) PB5 6 & & 35 PA5 (ADC5) \\
\hline (MISO) PB6 7 & & 34 PA6 (ADC6) \\
\hline (SCK) PB7 8 & & 33 PA7 (ADC7) \\
\hline RESET 9 & & 32 AREF \\
\hline $\operatorname{vcc} 10$ & & 31 GND \\
\hline GND $\longdiv { 1 1 }$ & & 30 AVCC \\
\hline XTAL2 12 & & $29 \mathrm{PC7}$ (TOSC2) \\
\hline XTAL1 13 & & 28 PC6 (TOSC1) \\
\hline (RXD) PD0 14 & & 27 PC5 (TDI) \\
\hline (TXD) PD1 15 & & 26 PC4 (TDO) \\
\hline (INTO) PD2 16 & & $25 \mathrm{PC} 3$ (TMS) \\
\hline (INT1) PD3 17 & & 24 PC2 (TCK) \\
\hline (OC1B) PD4 18 & & 23 PC1 (SDA) \\
\hline (OC1A) PD5 19 & & $22 \mathrm{PCO}(\mathrm{SCL})$ \\
\hline (ICP) PD6 20 & & 1 PD7 (OC2) \\
\hline
\end{tabular}

Gambar 1. Konfigurasi pin Atmega 32

\subsection{Serial UART}

Port serial pada komputer pada dasarnya menggunakan level RS-232 yang merupakan standar yang ditetapkan oleh EIA (Electronic Industry Association). Logika 1 pada RS-232 dinyatakan sebagai Mark dengan tegangan -3 volt sampai dengan -25 Volt (negatif). Logika 0 sebagai space dengan tegangan 3 Volt sampai dengan 25 Volt (positif). Berikut gambar 2 merupakan tampilan dari DB-9 pada komputer PC.

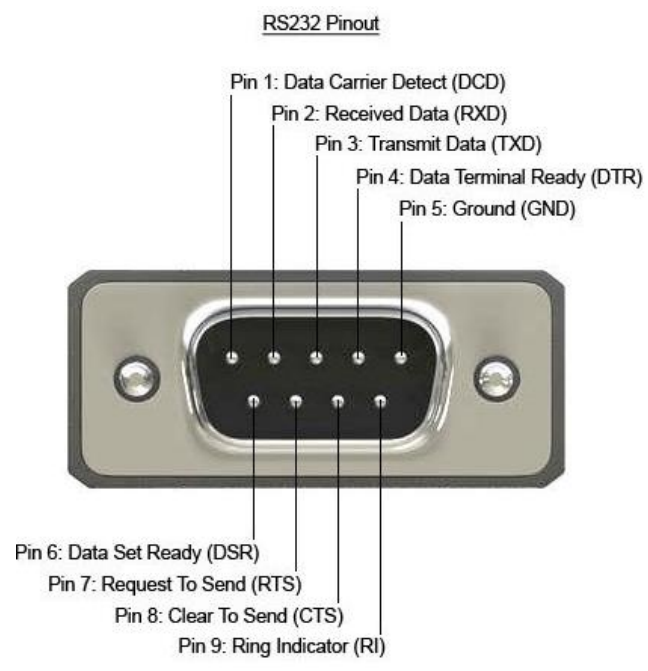

Gambar 2. Konektor DB-9 pada PC

\subsection{IC MAX232}

IC MAX232 merupakan IC keluaran dari Maxim Incoperation yang dapat merubah level TTL menjadi RS-232 atau sebaliknya. Dan memiliki charge pump yang dapat menghasilkan tegangan 10 Volt dan +10 Volt dengan catu daya 5 Volt. Tegangan ini dihasilkan dari proses pengisian dan pembuangan 4 kapasitor luar yang dikoneksikan dengan rangkaian pengganda tegangan internal yang telah dimiliki oleh IC MAX 232. IC MAX232 memiliki 2 receiver ( RS-232 ke TTL) dan 2 
Transmiter ( TTL ke RS-232), yang cukup untuk menyambungkan pin TXD fan RXD miktokontroller dengan modem YS-1020UB. Pada gambar 3 berikut, akan ditampilkan konfigurasi pin dari IC MAX232 [2].

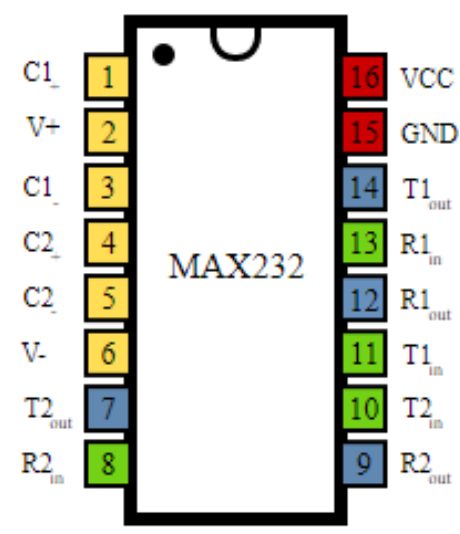

Gambar 3. Konfigurasi Pin IC MAX232

\subsection{Load Restance $2 \mathrm{Kg}$}

Load Cell adalah salah satu jenis sensor yang digunakan untuk mengubah daya tekan menjadi sinyal-sinyal listrik, melalui perubahan hambatan yang terjadi pada Strain Gauge dengan tekanan dalam bentuk deformasi (regangan) [3]. Pada umumnya load cell terdiri dari 4 susun Strain Gauge dalam konfigurasi jembatan wheatstone. Sinyal output dari load cell hanya ukuran mili volts, sehingga membutuhkan penguat deferensial sebelum digunakan. Output load cell diproses dalam algoritma yang terintegrasi untuk menghitung gaya yang diterapkan pada Strain Guage Load Cell [4]. Secara umum, tampilan fisik dari Load Cell seperti pada gambar 4 berikut ini.

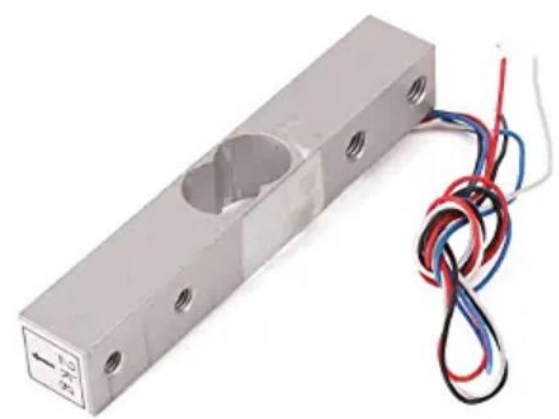

Gambar 4. Strain Guage Load Cell Resistance $2 \mathrm{Kg}$

\subsection{LCD ( Liquid Crystal Display )}

LCD adalah sebuah display dot matrix yang berfungsi untuk menampilkan tulisan baik berupa angka ataupun huruf sesuai dengan program yang diinginkan. Pada artikel ini, penulis menggunakan LCD dengan karakter $16 \times 2$. LCD juga merupakan sebuab mikrokontroller yang menempel pada suatu panel berfungsi untuk mangatur titik-titik huruf dan angka yang ditampilkan dikirim ke LCD dalam bentuk kode ASCII. Kode ASCII ini diterima dan diolah oleh mikrokontroller didalam LCD menjadi titik-titik LCD yang terbaca sebagai huruf dan angka. Gambar 6 berikut adalah konfigurasi pin dari LCD dengan karakter 16 × 2 . 


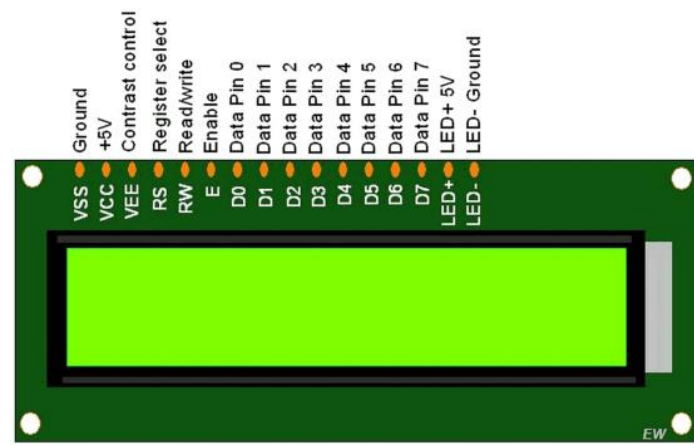

Gambar 6. Konfigurasi Pin LCD 16 x 2

\subsection{Motor Servo}

Motor servo adalah jenis motor yang dapat bekerja dua arah ( $\mathrm{CW}$ dan $\mathrm{CCW}$ ) dimana sudut dan arah pergerakannya dapat dikendalikan dengan memberikan pengaturan duty cycle sinyal PWM pada bagian pin kontrolnya [5]. Motor ini merupakan sebuah motor dengan sistem closed feedback dimana posisi motor akan di informasikan kembali ke rangkaian kontrol yang ada didalama motor servo. Gambar 7 berikut adalah motor servo parallax yang digunakan penelitian dalam arikel ini.

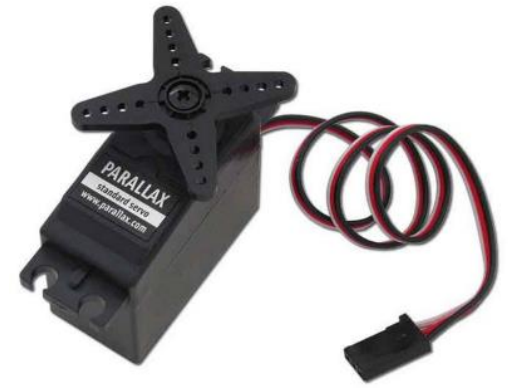

Gambar 7. Parallax Standart Servo

\section{METODE PENELITIAN}

\subsection{Perancangan Sistem}

Perancangan perangkat keras yang dirancang meliputi, pembuatan diagram blok secara keseluruhan serta pembuatan skema seluruh rangkaian yang dirancang. Diagram blok dari prototype sistem pemantau batas beban pada kapal penumpang secara diagram blok sebagaimana pada gambar 8 berikut:

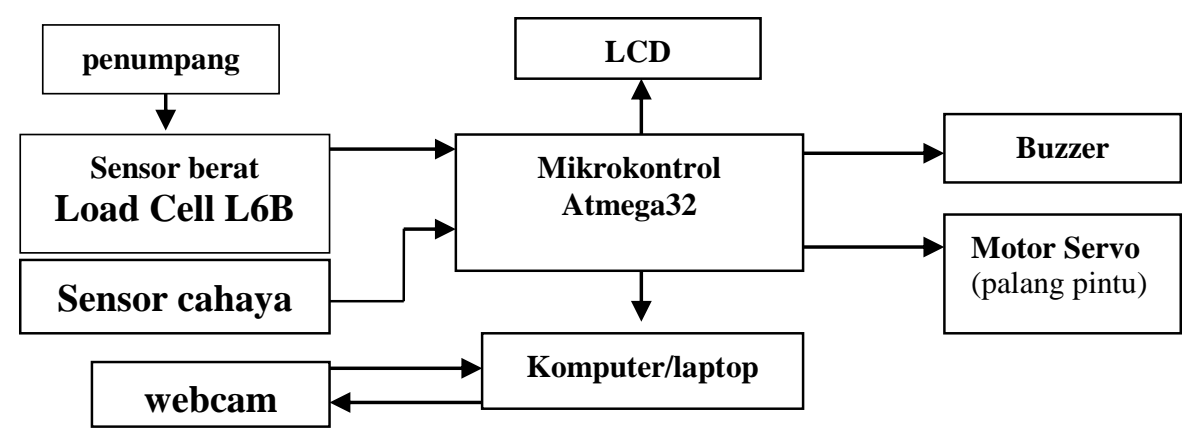

Gambar 8. Diagram Blok Sistem 


\subsection{Pembuatan Catu Daya}

Catu daya yang dirancang dalam artikel ini mampu menghasilkan tegangan keluaran 5 Volt DC, 12 Volt DC, -12 Volt DC dan hanya mampu menghasilkan arus maksimal sebesar 1 Ampere.

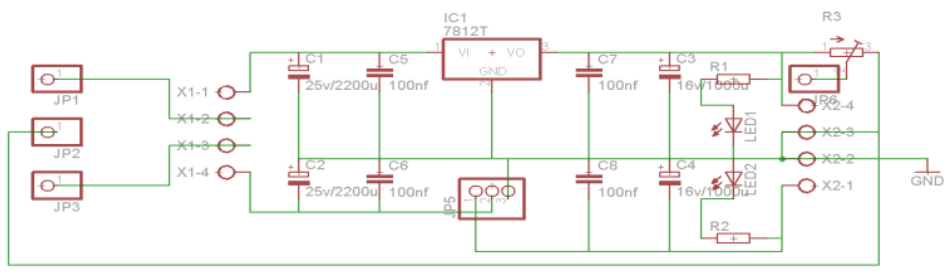

Gambar 9. Rangakaian Catu Daya

\subsection{Rangkaian Sistem Minimum Atmega32}

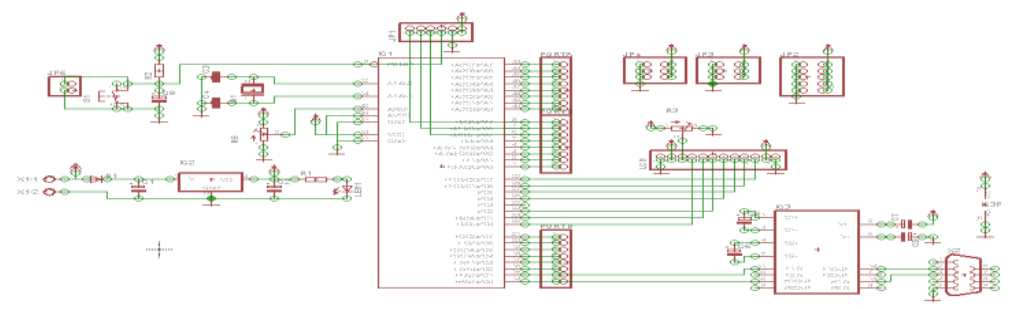

Gambar 10. Rangkaian Sistem Minimum ATMEGA32

Tabel 1. Pin / port yg digunakan

\begin{tabular}{ccl}
\hline No & Pin / Port & \multicolumn{1}{c}{ Keterangan } \\
\hline 1 & Pin b.1 & Sebagai tombol k1 \\
2 & Pin b.2 & Sebagai tombol reset k1 \\
3 & Pin b.3 & Sebagai tombol k2 \\
4 & Pin b.4 & Sebagai tombol reset k2 \\
5 & Pin a.4 & Sebagai tombol open 1 \\
6 & Pin a.5 & Sebagai tombol open 2 \\
7 & Pin a.6 & Untuk sensor cahaya 1 \\
8 & Pin a.7 & Untuk sensor cahaya 2 \\
9 & Port b.5 & Untuk buzzer \\
10 & Port b.6 & Untuk motor servo 1 \\
11 & Port b.7 & Untuk motor servo 2 \\
12 & Port c.0 & Untuk rs LCD \\
13 & Port c.1 & Untuk rw LCD \\
14 & Port c.2 & Untuk enable LCD \\
15 & Port c.4 & Untuk data 1 LCD \\
16 & Port c.5 & Untuk data 2 LCD \\
17 & Port c.6 & Untuk data 3 LCD \\
18 & Port c.7 & Untuk data 4 LCD \\
19 & Port d.0 & Untuk RX ( peneriama ) dari RS 232 \\
20 & Port d.1 & Untuk RT ( pengirim ) dari RS 232 \\
\hline
\end{tabular}

\subsection{Rangkaian Akuisisi Data Load Cell}

Keluaran yang dihasilkan oleh sensor massa load cell adalah tegangan dan hanya beberapa milli volts saja, sehingga membutuhkan amplifikasi/penguatan dengan penguat instrumentasi diferential sebelum digunakan. ditunjukkan pada Gambar 11 di bawah ini: 


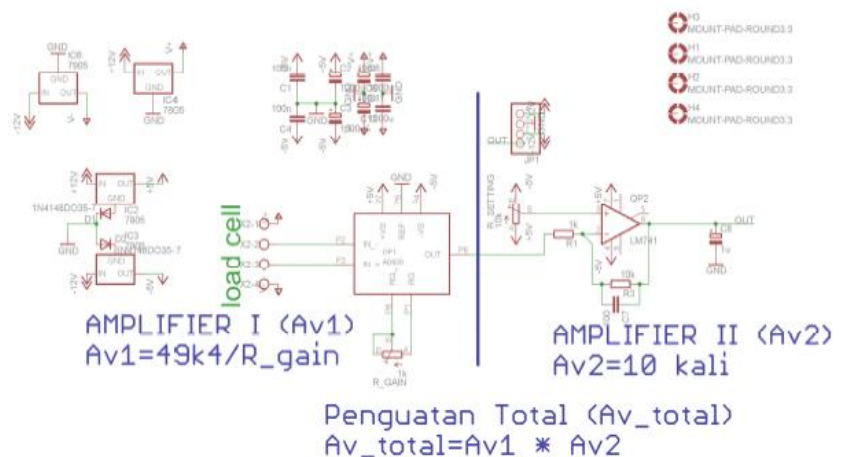

Gambar 11. Skema Penguat Load Cell

Sedangkan untuk perancangan pada perangkat lunak, mengacu pada gambar 12 diagram alir dibawah ini :

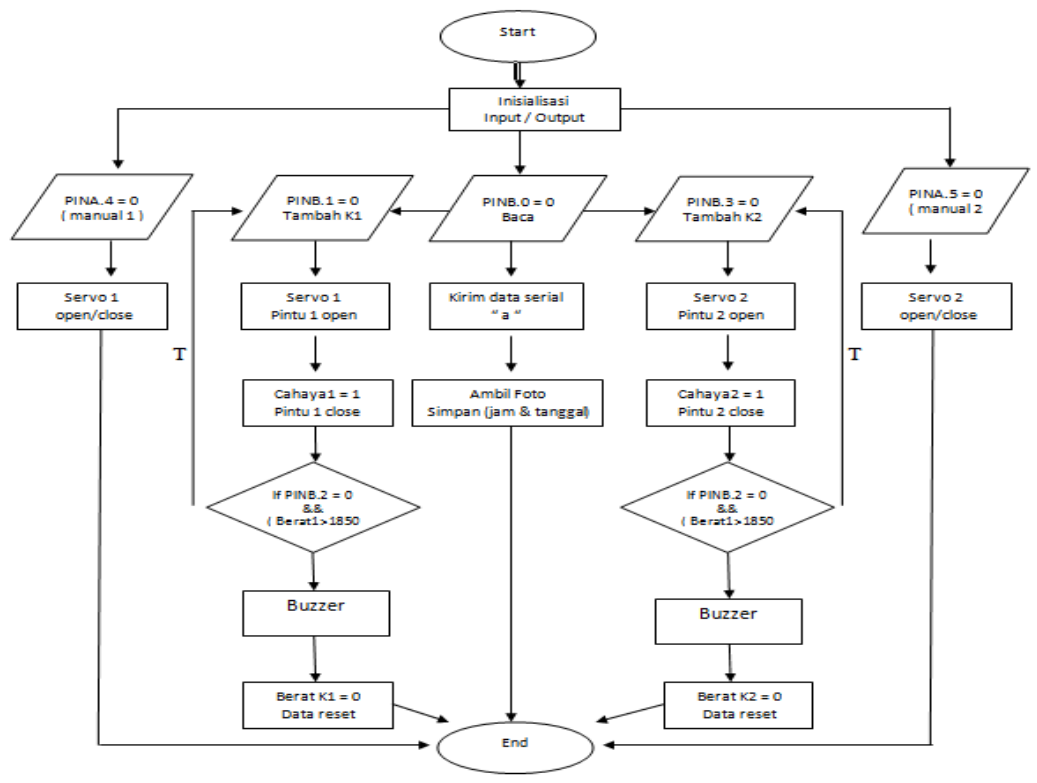

Gambar 12. Diagram Alir Sistem

\section{HASIL DAN PEMBAHASAN}

\subsection{Pengujian Tampilan LCD}

Pengujian pada LCD 16 × 2 dilakukan dengan tujuan memperoleh parameter berupa tampilan karakter pada LCD sesuai dengan program yang telah ditentukan. Pengujian dilakukan dengan memprogram karakter atau tulisan yang ingin ditampilkan pada LCD seperti tertera pada gambar 13 berikut.

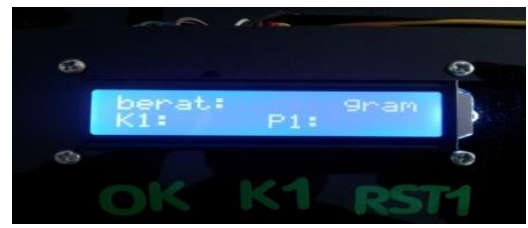

Gambar 13. Pengujian Display LCD 


\subsection{Pengujian Sensor Berat Load Cell Resistence $2 \mathrm{Kg}$}

Sebelum sensor berat digunakan terlebih dahulu dialukan kalibrasi dengan mengunakan anak timbanggan dengan berat 50 gram, 100 gram, 200 gram, 300 gram, 400 gram, 500 gram, 600 gram, 700 gram, 800 gram, 900 gram dan 1000, yang di tunjukkan pada tabel 2 berikut ini.

Tabel 2. Pengujian Sensor Berat Load Cell

\begin{tabular}{|c|c|c|c|c|c|c|c|c|c|}
\hline \multirow{2}{*}{$\begin{array}{c}\text { Anak } \\
\text { Timbangan } \\
\text { ( Gram ) }\end{array}$} & \multirow{2}{*}{$\begin{array}{c}\text { Tegangan } \\
\text { ( V ) }\end{array}$} & \multirow{2}{*}{$\begin{array}{l}\text { Nilai } \\
\text { ADC } \\
\text { ( Bit ) }\end{array}$} & \multicolumn{5}{|c|}{ Tampilan LCD ( Gram ) } & \multirow{2}{*}{$\begin{array}{l}\text { Berat } \\
\text { Rata- } \\
\text { Rata }\end{array}$} & \multirow{2}{*}{$\begin{array}{l}\text { Error } \\
(\%)\end{array}$} \\
\hline & & & 1 & 2 & 3 & 4 & 5 & & \\
\hline 0 & 0 & 0 & 0 & 0 & 0 & 0 & 0 & 0 & 0 \\
\hline 50 & 0.1 & 25 & 50 & 52.2 & 45,8 & 50,2 & 49.3 & 49,5 & 1 \\
\hline 100 & 0,2 & 51 & 105,5 & 100,2 & 99,8 & 100,3 & 99,5 & 101,1 & 1,1 \\
\hline 200 & 0,4 & 102 & 199,5 & 200,3 & 199,2 & 200,5 & 198,9 & 199,7 & 0,1 \\
\hline 300 & 0,7 & 153 & 301,5 & 300,5 & 299,7 & 302,3 & 299,2 & 300,6 & 0,2 \\
\hline 400 & 1,0 & 205 & 400,2 & 398,6 & 400,9 & 398,5 & 399,5 & 399,5 & 0,1 \\
\hline 500 & 1,2 & 256 & 501,4 & 499,8 & 499,1 & 502,3 & 498,5 & 500,2 & 0,04 \\
\hline 600 & 1,5 & 307 & 598,6 & 598,8 & 599,5 & 599,3 & 598.8 & 599 & 0,2 \\
\hline 700 & 1,7 & 358 & 699,1 & 699,6 & 699,5 & 701,5 & 699 & 699,7 & 0,04 \\
\hline 800 & 1,9 & 409 & 798,5 & 798,8 & 799,5 & 799,1 & 798,6 & 798,9 & 0,1 \\
\hline 900 & 2,2 & 461 & 897,3 & 899,1 & 898,3 & 899,3 & 899,8 & 898,7 & 0,1 \\
\hline 1000 & 2,5 & 512 & 998,9 & 997,5 & 999,2 & 999,5 & 998,7 & 998,7 & 0,1 \\
\hline \multicolumn{9}{|c|}{ Rata-Rata } & 0,3 \\
\hline
\end{tabular}

Dari data yang diperoleh pada tabel 2 dengan melakukan pengujian pada 11 anak timbangan dengan berat 50 gram sampai dengan 1000 gram dan masing - masing sampel diuji sebanyak 5 kali masih terdapat error rata - rata sebesar $0,3 \%$ yang merupakan efek dari faktor mekanik, pemilihan komponen dan power suplay yang masih terdapat ripple.

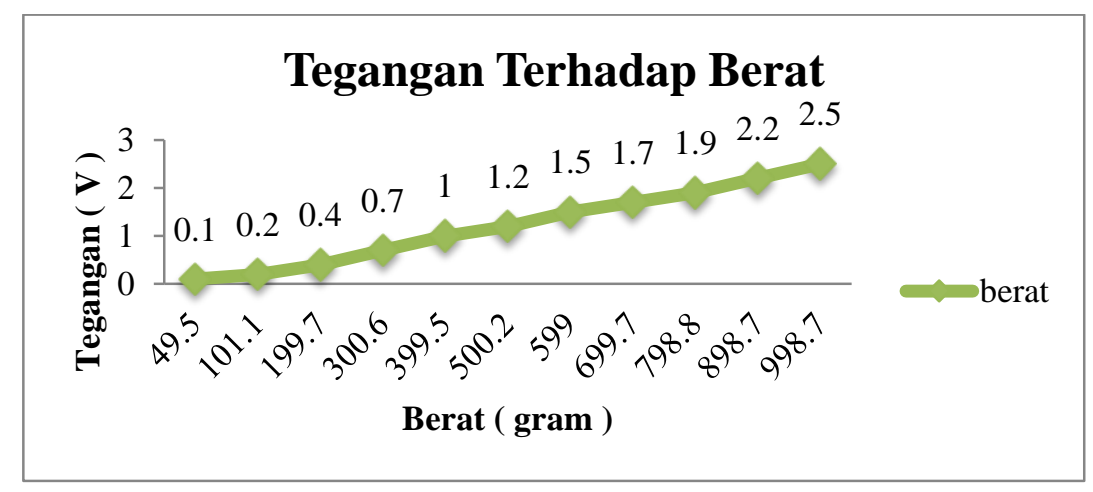

Gambar 14. Grafik Tegangan ( V ) Terhadap Berat ( gram )

Dari grafik hubungan tegangan ( V ) terhadap berat ( gram ) yang ditunjukan pada Gambar 14 . didapatkan hasil mendekati linier.

- $\quad$ Rata - Rata $=$ Jumlah Semua Percobaan : Jumlah Percobaan

Contoh :

Rat - rata $=50+52,2+48,5+50,2+49,3+49,5=49,5$

Dst...

- $\quad$ Error $=\frac{N-X}{N} \times 100 \%$

Dimana :

$\mathrm{N}=$ Anak Timbangan

$\mathrm{X}=$ Nilai Percobaan

Contoh : 
Error $=\frac{50-49,5}{50} \times 100 \%=1 \%$

Dst...

- $\quad$ Error rata - rata $=$ jumlah semua error : banyak sampel

Error rata - rata $=3,08: 11=0,3 \%$

\subsection{Pengujian Sensor Cahaya}

Pengujian sensor cahaya dilakukan dengan cara menghalangi cahaya yang akan menuju pada photodioda pada saat photodioda mendapat cahaya maka akan berlogika 1 yang ditandai dengan padamnya lampu indikator, dan jika phothodioda tidak mendapat cahaya maka akan berlogika 0 yang ditandai dengan hidupnya lampu indikator hal ini ditunjukan pada Tabel 3.

Tabel 3. Pengujian Sensor Cahaya

\begin{tabular}{cccccc}
\hline No & Cahaya & $\begin{array}{c}\text { Sensor } \\
\text { Cahaya 1 }\end{array}$ & $\begin{array}{c}\text { Sensor } \\
\text { Cahaya 2 }\end{array}$ & $\begin{array}{c}\text { Indikator } \\
\text { Lampu }\end{array}$ & Keterangan \\
\hline 1 & Ada & 1 & 1 & Padam & Berhasil \\
2 & Tidak & 0 & 0 & Hidup & Berhasil \\
\hline
\end{tabular}

\subsection{Pengujian Push Button}

Pengujian push button dilakukan untuk mengetahui apakah tombol sudah berfungsi sebagai mana mestinya dan sesuai dengan kegunaanya masing - masing pengujian ini dilakukan sebanyak 5 kali pada setiap push bottom dan didapatkan hasil seperti Tabel 4.

Tabel 4. Pengujian Push Button

\begin{tabular}{|c|c|c|c|c|c|c|}
\hline \multirow[b]{2}{*}{ No } & \multirow{2}{*}{$\begin{array}{c}\text { Pin } \\
\text { Aktif } \\
\text { Low }\end{array}$} & \multirow[b]{2}{*}{ Fungsi } & \multicolumn{4}{|c|}{ Percobaan } \\
\hline & & & 1 & 2 & 3 & 4 \\
\hline 1 & Pin b.0 & Timbang & Berhasil & Berhasil & Berhasil & Berhasil \\
\hline 2 & Pin b. 1 & Tambah k1 & Berhasil & Berhasil & Berhasil & Berhasil \\
\hline 3 & Pin b. 2 & Reset k1 & Berhasil & Berhasil & Berhasil & Berhasil \\
\hline 4 & Pin b. 3 & Tambah k2 & Berhasil & Berhasil & Berhasil & Berhasil \\
\hline 5 & Pin b.4 & Reset k2 & Berhasil & Berhasil & Berhasil & Berhasil \\
\hline 6 & Pin a 4 & Open k1 & Berhasil & Berhasil & Berhasil & Berhasil \\
\hline 7 & Pin a.5 & Open k2 & Berhasil & Berhasil & Berhasil & Berhasil \\
\hline
\end{tabular}

\subsection{Pengujian Motor Servo}

Pengujian motor servo dilakukan untuk mengetahui apakah motor servo dapat berputar sesuai dengan yang diinginkan dan layak untuk digunakan. Pengujian ini dilakukan dengan cara memberikan program pada mikrokontroler terlebih dahulu. Program tersebut merupakan program untuk memberikan perintah kepada motor servo agar memutar motor servo ke posisi $90^{\circ}$ disaat berat muatan kapal $<1850$ gram dan tetap pada posisi $0^{\circ}$ disaat berat muatan kapal $\geq 1850$ gram ditunjukan pada Tabel 5 .

Tabel 5. Pengujian Motor Servo

\begin{tabular}{cclc}
\hline No & Berat pada LCD & \multicolumn{1}{c}{ Aksi Motor Servo } & Keterangan \\
\hline 1 & 0 & Tetap pada posisi awal $0^{\circ}$ & Berhasil \\
2 & 100 & Berputar otomatis searah jarum jam 90 & Berhasil \\
3 & 200 & Berputar otomatis searah jarum jam 90 & Berhasil \\
4 & 300 & Berputar otomatis searah jarum jam 90 & Berhasil \\
5 & 400 & Berputar otomatis searah jarum jam 90 & Berhasil \\
6 & 500 & Berputar otomatis searah jarum jam 90 & Berhasil \\
7 & 600 & Berputar otomatis searah jarum jam 90 & Berhasil \\
8 & 700 & Berputar otomatis searah jarum jam 90 & Berhasil \\
\hline
\end{tabular}




\begin{tabular}{ccll}
\hline 9 & 800 & Berputar otomatis searah jarum jam 90 & Berhasil \\
10 & 900 & Berputar otomatis searah jarum jam 90 & Berhasil \\
11 & 1000 & Berputar otomatis searah jarum jam 90 & Berhasil \\
12 & 1100 & Berputar otomatis searah jarum jam 90 & Berhasil \\
13 & 1200 & Berputar otomatis searah jarum jam 90 & Berhasil \\
14 & 1300 & Berputar otomatis searah jarum jam 90 & Berhasil \\
15 & 1400 & Berputar otomatis searah jarum jam 90 & Berhasil \\
16 & 1500 & Berputar otomatis searah jarum jam 90 & Berhasil \\
17 & 1600 & Berputar otomatis searah jarum jam 90 & Berhasil \\
18 & 1700 & Berputar otomatis searah jarum jam 90 & Berhasil \\
19 & 1800 & Berputar otomatis searah jarum jam 90 & Berhasil \\
20 & 1900 & Tetap pada posisi awal 0 & Berhasil \\
\hline
\end{tabular}

\subsection{Pengujian Komunikasi Serial Rs-232}

Pengujian ini dilakukan dengan cara mengkoneksikan port RS-232 dengan com 1 pada pc atau laptop. Selanjutnya menghubungkan pin 1 dengan graund serta pin 4 dengan VCC yang terdapat pada JP1 rangkaian komunikasi serial, setelah itu menghubung singkatkan pin 2 dan pin 3 yang ada pada JP 1. Selanjudnya buka program hyperterminal pada PC atau laptop, kemudian menekan tombol pada kayboard, apa bila tombol yang ditekan muncul pada hyperterminal maka komunikasi serial telah berfungsi, hasilnya ditunjukan oleh Gambar 15.

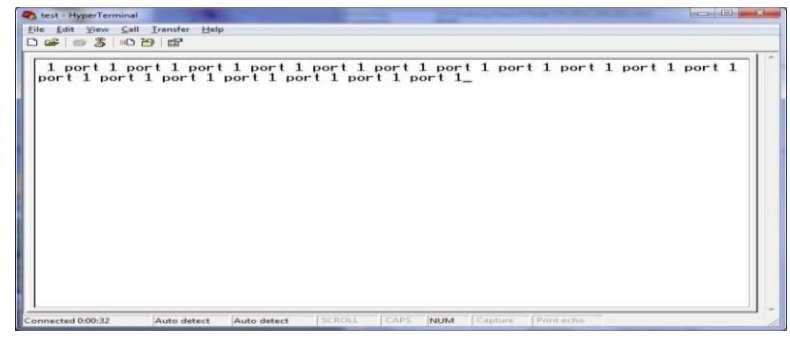

Gambar 16. Pengujian Komunikasi Serial RS-232

\subsection{Pengujian Webcam}

Percobaan ini dilakukan untuk mengetahui pakah webcam telah terhubung dengan komputer atau laptop dan bisa bekerja dengan mengunakan aplikasi Visual Basic 6.0. langkah langkanya adalah open aplikasi sistem pemantau berat kendaraan klik mulai pada webcam visual basic jika terhubung akan keluar tampilan seperti Gambar 17.

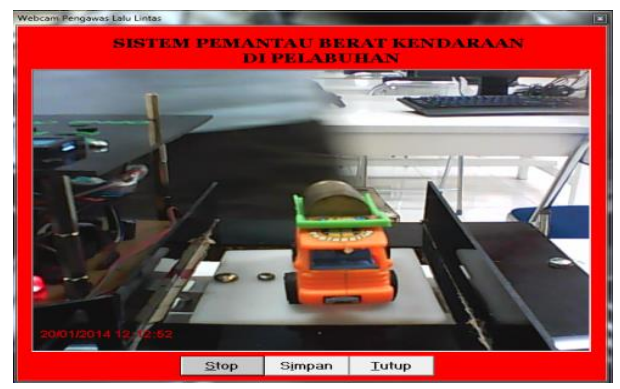

Gambar 17. Tampilan Webcam Visual Basic 6.0

Setelah dilakukan penimbangan dan pengambilan gambar maka akan disimpan hasilnya akan tersimpan pada folder foto seperti yang ditunjukan pada Gambar 18. 


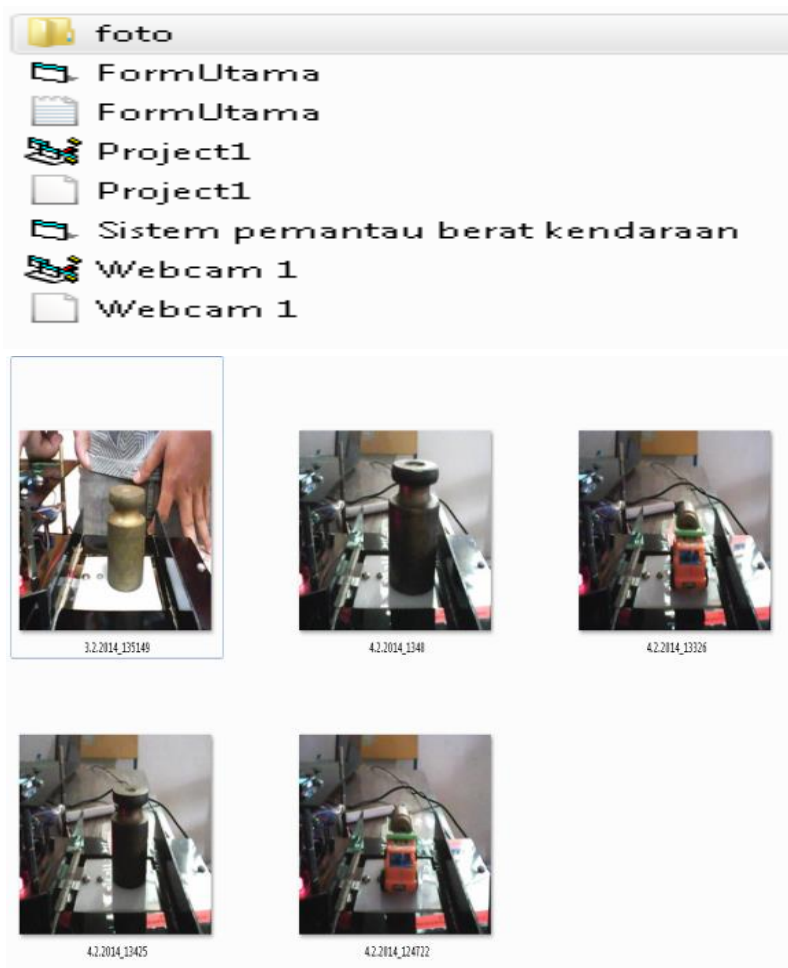

Gambar 18. Folder dan Pennyimpanan Gambar Visual Basic

\section{KESIMPULAN}

Berdasarkan pengujian dan analisis yang dilakukan dapat disimpulkan bahwa:

1. Alat yang dibuat sudah bekerja dengan baik sesuai dengan hasil yang diharapkan.

2. Dari data berat mauatan terdapat error rata - rata 0,3\% yang merupakan efek dari faktor mekanik dan penggunaan power supply yangmasih terdapat ripple.

3. Alat ini dapat menimbang dengan berat beban 0 sampai 1.600 gram karena otput dari load cell hanya maksimal 4 volt.

4. Dari hasil pengambilan gambar yang dilakukan didapatkan hasil foto mengunakan format JPEG dengan dimensi 629 x 469 dan memori sebesar $864 \mathrm{~kb}$. Yang tersimpan dalam 1 folder foto dikarenakan pritotype ini hanya mengunakan 1 webcam.

\section{REFERENSI}

[1] Clifford Andika Onibala, "Lex et Societatis," vol. III, no. 4, pp. 81-88, 2015.

[2] D. Information, "MAX232x Dual EIA-232 Drivers/Receivers,” Texas Instrum., 2014.

[3] B. Willy, "Rancang bangun timbangan digital dengan pemilihan jenis buah / Willy Bayu Erlangga Author: Erlangga, Willy Bayu,” p. 5.

[4] E. H. Rusnindyo et al., "Sensor Massa Untuk Mengukur Derajat Layu Pada Pengolahan Teh Hitam," vol. 8, no. June 2015, pp. 1-6, 2015.

[5] Purwanto, "Pengendali Motor Servo Dc Standard Dengan Berbasis Mikrokontroler AVR," no. 021, 2009. 


\section{BIOGRAFI PENULIS}

Iswahyudi lahir di Jember pada tanggal 22 Januari 1983 anak pertama dari kelima bersaudara
ini lulusan S1 Teknik Elektro Universitas Muhammadiyah Jember, aktifitas sehari-hari
sebagai Laboran di Lab Robotika juga masih aktif Kuliah S2 di Jurusan Teknik Elektro
Universitas Jember. Bidang Keahlian Elektronika dan Mikrokontroller.

